\title{
Does Indigenous Knowledge Occur in and Influence Impact Assessment Reports? Exploring Consultation Remarks in Three Cases of Mining Projects in Greenland
}

\author{
Parnuna Petrina Egede Dahl \\ PhD Fellow
}

\author{
Anne Merrild Hansen* \\ Aalborg University
}

\begin{abstract}
Mineral extraction is pursued in Greenland to strengthen the national economy. In order that new industries promote sustainable development, environmental impact assessments and social impact assessments are legally required and undertaken by companies prior to license approval to inform decision-making. Knowledge systems in Arctic indigenous communities have evolved through adaptive processes over generations, and indigenous knowledge (IK) is considered a great source of information on local environments and related ecosystem services. In Greenland the Inuit are in the majority, and Greenlanders are still considered indigenous. The Inuit Circumpolar Council stresses that utilizing IK is highly relevant in the Greenland context. Impact assessment processes involve stakeholder engagement and public participation, and hence offer arenas for potential knowledge sharing and thereby the utilization of IK. Based on the assumption that IK is a valuable knowledge resource, which can supplement and improve impact assessments in Greenland thus supporting sustainable development, this paper presents an investigation of how IK is utilized in the last stages of an impact assessment process when the final report is subject to a hearing in three recent mining projects in Greenland.
\end{abstract}

Keywords: Arctic; Greenland; EIA; SIA; extractive industries; indigenous knowledge; traditional knowledge; impact assessment

Responsible Editor: Noor Johnson, University of Colorado, Boulder

Received: August 2018; Accepted: November 2019; Published: December 2019

^Correspondence to: Anne Merrild Hansen, email: merrild@plan.aau.dk

(C) 2019 Parnuna Petrina Egede Dahl \& Anne Merrild Hansen. This is an Open Access article distributed under the terms of the Creative Commons Attribution-NonCommercial 4.0 International License (https://creativecommons.org/licenses/ by-nc/4.0/), allowing third parties to share their work (copy, distribute, transmit) and to adapt it, under the condition that the authors are given credit, that the work is not used for commercial purposes, and that in the event of reuse or distribution, the terms of this license are made clear.

Citation: Parnuna Petrina Egede Dahl E Anne Merrild Hansen. "Does Indigenous Knowledge Occur in and Influence Impact Assessment Reports? Exploring Consultation Remarks in Three Cases of Mining Projects in Greenland" Arctic Review on Law and Politics, Vol. 10, 2019, pp. 165-189. http://dx.doi.org/10.23865/arctic.v10.1344 


\section{Introduction}

The government of Greenland supports a strategy to attract international investors and companies that develop activities in the mineral resource sector in Greenland. The government sees the strategy as one way of promoting prosperity and welfare for Greenlandic society. ${ }^{1}$ Although the government considers hydrocarbon and mineral extraction as activities that can support local and national development, citizens in different parts of Greenland have opposed proposed extractive industry projects for a variety of reasons. ${ }^{2}$ They express reluctance to support extractive activities if the activities compromise what they consider their main livelihoods, such as sheep farming in south Greenland, tourism in west and east Greenland, or fisheries in northwest Greenland. ${ }^{3}$ Traditions and established employment opportunities come first, but if extractive industries can develop hand in hand with community development without compromising environmental integrity, then citizens are broadly supportive. ${ }^{4}$ A positive attitude from local residents creates a beneficial business environment for mining companies, the maintenance of which requires care, as mining activities can create desirable outcomes for local communities, but can also cause undesired impacts and harm, for example by compromising traditional activities such as subsistence hunting. ${ }^{5}$ It is therefore important to plan with care and protect local interests when new extractive projects are implemented.

In Greenland, the Inuit make up the majority of the population, approximately 80 percent. ${ }^{6}$ The government of Greenland also formally recognizes the Inuit living in Greenland as an Indigenous people. Through the Kingdom of Denmark, Greenland has ratified the International Labour Organization's Indigenous and Tribal Peoples Convention, 1989 (No. 169) (ILO C169), and adopted the UN Declaration on the Rights of Indigenous Peoples (UN DRIP). ${ }^{7}$ Interestingly however, the Act on Greenland Self-Government itself does not contain any language relating to Indigenous peoples. ${ }^{8}$ Still, in considering the need for careful planning to accommodate the increasing level of industrial development activities in Greenland, informally acquired skills and indigenous knowledge have been broadly identified as complementary qualifications and potentially useful competences in decision-making processes in the gradual transition from traditional to modern industries. ${ }^{9}$ The Inuit Circumpolar Council - Greenland, for example, has suggested that the utilization of indigenous knowledge is highly relevant to the development of impact assessments in the Greenlandic context. ${ }^{10}$

Critical voices have been raised questioning whether indigenous knowledge can be incorporated into assessments and other bureaucratic formats. ${ }^{11}$ This paper does not go into that discussion, but rather starts with the assumption that there are potential benefits in utilizing indigenous knowledge in decision-making processes relating to capacity building and the promotion of sustainable development. This is in line with several of the Arctic Council declarations, which have emphasized how using traditional knowledge (in this context understood as indigenous knowledge) is essential for a sustainable future in the Arctic. ${ }^{12}$ 
Methodologically, there are different approaches to incorporating indigenous knowledge in environmental impact assessments (EIA) and social impact assessments (SIA). For example, one of the basic principles of EIA according to the International Association of Impact Assessment (IAIA) is to use an interdisciplinary process that employs appropriate experts in relevant fields, including the use of traditional knowledge ${ }^{13}$ (in this context understood as indigenous knowledge). To operationalize this process, the IAIA has developed international best practice principles to promote a meaningful integration of traditional knowledge as well as the respectful incorporation of Indigenous peoples in impact assessments in general. ${ }^{14}$ These operating principles, as well as additional sources, ${ }^{15}$ include recommendations that it should be up to the Indigenous peoples to identify who their knowledge holders are, and that they should be involved in determining the research questions and methodologies relating to how their knowledge should be collected and interpreted.

While there is substantial literature available on levels of participation and meaningful engagement of Indigenous peoples in impact assessment processes in the Arctic, studies focused on the utilization of indigenous knowledge in impact assessment conclusions and outcomes are still limited. ${ }^{16}$ Recent studies have found, however, that practice is moving toward co-production of impact assessments, with developments driven by strong indigenous demands and the political recognition of material rights to land and resources. ${ }^{17}$ This could indicate that indigenous knowledge is gaining more prominence within Arctic science, and is therefore more readily available to feed into impact assessments. This growing role of indigenous knowledge in impact assessment processes does not necessarily result in the outcomes that indigenous participants desire, however. For example, the inclusion of indigenous knowledge has rarely led to the rejection of unwanted projects altogether. Additionally, community influence in impact assessment tends to be in evidence generation and follow-up, while developers or state authorities retain control over the critical phases of scoping and determining how impact significance is assessed. ${ }^{18}$ Overall, the level of indigenous influence on impact assessment conclusions and outcomes seems to be limited.

In Greenland, separate EIA and SIA guidelines are implemented to support decision-making in relation to permitting extractive projects and promoting sustainable development in communities when new extractive projects are developed. The public consultation meetings entailed in these processes are not specifically designed to solicit indigenous knowledge, however, and there is no generally acknowledged method for identifying indigenous knowledge in such engagement processes. Similarly, there is currently no way to evaluate the degree of utilization of indigenous knowledge in impact assessment processes. In this paper, we investigate the degree to which indigenous knowledge is utilized in impact assessment processes conducted as part of the licensing process for mining projects in Greenland and fed into the resulting reports. 
The study presented is exploratory in its approach with a twofold purpose: to find out if and how this potential resource of indigenous knowledge is utilized (brought into key arenas); and to theorize about how the recognition and documentation of indigenous knowledge in impact assessment processes can be improved.

In the following sections we first discuss some of the ways that indigenous knowledge is conceptualized, and describe how we interpret the knowledge concept in our investigation. We then present the regulatory context of impact assessments related to extractive projects in Greenland and identify key arenas for utilizing indigenous knowledge. Subsequently, we describe how we analyzed three cases of impact assessment processes for mining projects in Greenland to see if and how indigenous knowledge influenced the content of the impact assessment reports.

\section{Conceptualizing indigenous knowledge}

People who live off the land and the sea, such as hunters, fishermen and farmers, depend on observing and interpreting signs in their surrounding environments. ${ }^{19} \mathrm{It}$ is essential for these people and the communities in which they reside, to acquire knowledge about signs, patterns and variations in nature. It is also important for them to pass on their knowledge and share their experiences, as these relate to cohabitation with their environment and thus the communities' continued existence. ${ }^{20}$ These types of environmental knowledge are recognized in many parts of the Arctic, often related to practices of subsistence hunting and gathering, fishing and herding. ${ }^{21}$ Knowledge about the environment is typically passed on from individual to individual through the generations; and this sharing of knowledge is built into traditional customs facilitated through formal and informal training and practices of traditional communal activities. In several areas of the Arctic, a majority of local household economies are either directly or indirectly involved in the harvesting of renewable resources and thus continue to rely on the inherently developed knowledge systems.

Within the context of Arctic indigenous communities, there is a wide variety of knowledge concepts used to describe the knowledge of Indigenous peoples, the most frequently used and widely referenced being traditional knowledge, and increasingly, indigenous knowledge. ${ }^{22}$ Other examples are traditional ecological knowledge and local knowledge, ${ }^{23}$ ranging from " $k$ nowledge about the environment, knowledge about the use of the environment, values about the environment, and the knowledge system itself" to concepts in local knowledge as part of social, cultural and political processes happening at the local, national and global levels. ${ }^{25}$

Inuit Qaujimajatuqangit is another knowledge concept, which can be considered a subset of indigenous knowledge. It has been introduced by Inuit organizations in Nunavut, Canada, and covers Inuit traditional knowledge, as well as contemporary Inuit knowledge, and reflects Inuit cosmology, societal values and experience. ${ }^{26}$ George Wenzel ${ }^{27}$ has argued that Inuit Qaujimajatuqangit appears more inclusive by recognizing the social value of everyday and representative aspects of indigenous 
knowledge. One of the guiding precepts of Inuit Qaujimajatuqangit relates to the principle of 'Pilimmaksarniq', which refers to the acquisition of knowledge and skills and the improvement of skill through practice. ${ }^{28}$ Wenzel suggests that this principle helps illustrate the general problem of divorcing knowledge from whatever social context or process of learning it originally emerged from. Processes of labeling or defining knowledge in fixed ways fail to capture fully what is often a dynamic and flexible subsistence practice. As Wenzel suggests, "The fact that Inuit Qaujimajatuqangit is often equated with traditional ecological knowledge [...] diminishes the depth of its sociocultural content (and importance)" ${ }^{29}$ This is also reflected by Noor Johnson, stating that "Inuit knowledge cannot be divorced from economic life, kinship, the land, animals, or emotional experience; it is fed by and feeds into each of these"..$^{30}$

The Inuit Circumpolar Council, one of the six Indigenous peoples' organizations recognized as Permanent Participants in the Arctic Council, originally used the term traditional knowledge. ${ }^{31}$ Together with the other Permanent Participants, they also agreed to use the term traditional knowledge in the work of the Arctic Council and developed the Ottawa Traditional Knowledge Principles ${ }^{32}$ in 2015. This term was not intended to replace other terms or definitions used by individual organizations on a national level. Later, the Inuit Circumpolar Council changed their own term from traditional knowledge to indigenous knowledge ${ }^{33}$ in order to reflect more adequately the indigenous aspect of the knowledge, while otherwise retaining the same definition of the knowledge concept. This transition was later echoed by the other Permanent Participants in October 2018, leading to changing the term in the Ottawa Principles to indigenous knowledge. ${ }^{34}$ Throughout the rest of the article, we will be using the Inuit Circumpolar Council definition of indigenous knowledge ${ }^{35}$ as:

... A systematic way of thinking applied to phenomena across biological, physical, cultural and spiritual systems. It includes insights based on evidence acquired through direct and longterm experiences and extensive and multigenerational observations, lessons and skills. It has developed over millennia and is still developing in a living process, including knowledge acquired today and in the future, and it is passed on from generation to generation.

\subsection{Assessing indigenous knowledge in impact assessments}

Indigenous knowledge is not necessarily easy to document and assess, and due consideration must be observed in relation to, for example, local customs and traditional land tenure systems, as well as indigenous cultural and intellectual property rights in the Arctic. ${ }^{36} \mathrm{~A}$ significant proportion of the literature on indigenous knowledge in an Arctic context, as discussed here, concerns the implications of framing indigenous knowledge for managerial purposes, such as the administration of hunting quotas in Greenland. ${ }^{37}$

In the study presented here, in order to capture both the ecological and cultural content, we have chosen to identify topics relevant to indigenous knowledge as any knowledge about (the list is not exhaustive and not in prioritized order): 


\section{Parnuna Petrina Egede Dahl E Anne Merrild Hansen}

- The environment in general, including ecological links

- Animals, including distribution, migration and behavior

- Plants, including distribution

- Climate, including currents, winds, snow, ice and seasonality

- Traditional activities, including use of land and water for hunting and gathering, fishing, recreation and navigation

- Culture, including past and present traditions, values, beliefs and priorities

- Traditional foods, including preparation and storage

- History of people and landscapes

- Traditional rights, including customary law

\section{Greenlandic impact assessment regimes}

On June 21, 2009, the Act on Greenland Self-Government came into force. This allowed the government of Greenland to assume responsibility for mineral resources and thereby have the right to utilize and earn revenue from hydrocarbons and minerals in the subsoil of Greenland. Greenland consequently adopted the Act on Mineral Resources and Mineral Resource Activities (the Mineral Resources Act) on December 7, 2009, and took home the responsibility for the mineral resource sector on January 1, 2010 from its former colonial power, Denmark. The Mineral Resources Act contains provisions that regulate environmental as well as social impacts from mineral resource activities.

The Mineral Resources Act, part 15, section 73 stipulates that an EIA must be conducted prior to any development activity if it is assumed to have a significant impact on the environment, and that the EIA report must be approved by the government of Greenland before a mineral resource activity can be allowed. Exploitation of hydrocarbons and mineral resources including construction, operation, subsoil storage and closure of activities and facilities are all activities assumed by scientific advisors to the Greenland government to have a significant impact on the environment. Other activities that have triggered EIAs include seismic surveys and exploratory drilling programs for offshore hydrocarbon wells.

Similarly, part 16, section 76 of the Mineral Resources Act stipulates that a social sustainability assessment (otherwise reminiscent of, and used synonymously with, an SIA) has to be conducted if a mineral resource activity is assumed to have a significant impact on social conditions. The government of Greenland must approve the SIA report before a mineral resource activity can be allowed. Two mineral resource activities have so far been assumed by scientific advisors to the Greenland government to have a potential significant impact on social sustainability: 1) exploratory drilling programs for hydrocarbon wells and 2) constructing and operating mines. In essence, except for seismic activities, the same mineral resource activities that trigger an EIA will also trigger an SIA. ${ }^{38}$ 
Sections 74 and 77 of the Mineral Resources Act stipulate that it is the applicant for the license who must prepare impact assessment reports. The impact assessment regimes for extractive industry projects in Greenland are in this way rooted in the Mineral Resources Act. The Act is a framework of legislation that specifies the overall structure of the internal procedures. It is supported by formal guidelines with detailed requirements for preparing EIA reports for hydrocarbon and mineral resource activities, and guidelines for the process and preparation of the SIA report for mineral projects. For the SIA process, the Ministry of Industry, Labor, Trade and Energy is the responsible authority. For the EIA process, the Environmental Agency for Mineral Resource Activities (EAMRA), an agency under the Ministry of Nature and Environment, is responsible for environmental issues including the EIA process. The Mineral License and Safety Authority (MLSA), an agency under the Ministry of Mineral Resources, Labor and the Interior, is responsible for coordinating and licensing. ${ }^{39}$

\subsection{Indigenous knowledge in Greenlandic impact assessment regimes}

Examples of indigenous, traditional, local or user knowledge are occasionally shared by Greenlanders in national media outlets, for example when speaking about climate changes or fishing and hunting regulations. Indigenous knowledge has been successfully engaged, documented and employed in Greenlandic cases where locally based environmental monitoring projects have been tested and subsequently acknowledged by the scientific community. ${ }^{40}$ In spite of these examples, however, official recognition and formal acceptance by the authorities in Greenland of the usefulness of indigenous knowledge in relation to industrial activities is still lacking.

In the mineral resource sector in Greenland, the use of indigenous knowledge in official documents is neither prominent nor consistent, possibly reflecting different professional perceptions resulting in varying understanding of what knowledge is considered legitimate in different sectors. Within the hydrocarbon sector, looking at the language used in the official guidelines for preparing EIAs reveals that only scientific knowledge and information is referred to as a legitimate knowledge source. Indigenous knowledge holders are referred to as "local authorities, stakeholders, and the general public" and their engagement process is limited to public consultations through a hearing process and review of the EIA report. ${ }^{41}$ The guidelines that come closest to mentioning topics related to indigenous knowledge are the offshore seismic guidelines, ${ }^{42}$ which note, "Whales and seals are important for the Greenland subsistence hunt, and especially the summer hunt for narwhals in Melville Bay is at risk of being impacted by seismic surveys".

Within the mineral sector, the Greenlandic SIA guidelines for the process and preparation of the SIA report for mineral projects use the terms 'traditional knowledge' and 'local knowledge', and it seems that the two terms are used almost synonymously in this context, as can be seen in following sections: 
The company is obliged to involve relevant stakeholders and apply local knowledge in connection with preparing this report. ${ }^{43}$ (p. 15)

When preparing the SIA report, the company must use traditional and local knowledge as far as possible by collecting information through qualitative interviews. It is important to incorporate local knowledge from individuals, commercial hunters and fishermen etc. This knowledge may have been passed on from generation to generation and has not necessarily been described and analysed in publications and public literature. It is recommended that the licensee describes, analyses and uses the traditional knowledge existing in the area in the SIA report. This knowledge may also include municipal planning documents and similar descriptions. ${ }^{44}$ (p. 24)

In the guidelines for preparing an EIA report for mineral exploitation in Greenland, there is no mention of 'traditional knowledge'. Instead, the term used is 'local knowledge', and the focus seems to be on 'local use' including conflict mitigation, as can be seen in the following sections:

The environmental baseline studies shall cover at least the following issues:

- Chemical and eco-toxicological aspects (pollution)

- Disturbance aspects (impacts on flora and fauna)

- Local use and local knowledge study $y^{45}$ (p. 9)

The information can be obtained from own [sic] specific field studies, from published information (e.g. DCE and GINR reports) and from local knowledge. ${ }^{46}$ (p. 10)

Local use and local knowledge study: It is important to include local knowledge in the preparation of the EIA report. Special attention shall be aimed at mitigating conflicts between the mining activities and the local use of the area for hunting, fishing, recreation and tourism. Inclusion of local knowledge can be through interviews with and questionnaires distributed to representative groups such as local hunters and fishermen, tourist operators and local industries. ${ }^{47}$ (p. 10)

The guidelines on EIAs and SIAs in Greenland define when interaction is to take place between stakeholders, including the consultants, the company applying for a license, the public and others. Interaction and communication are considered prerequisites for potential knowledge sharing. For example, the SIA guidelines declare that:

The process of preparing a Social Impact Assessment is characterized by having a high degree of public participation before, during and after the launch of a project. The aim is that all relevant stakeholders must be informed about the project and heard in the process, be given the opportunity to contribute with knowledge about e.g. local conditions, and be active in the work and the decision-making process in proposals for location of installations etc. In connection with preparing an SIA report, knowledge and experience from people familiar with Greenlandic conditions must be included as far as possible. It is therefore recommended that local individuals, local consultants and enterprises be involved in this process as far as possible. ${ }^{48}$ (p. 23)

To summarize, the term indigenous knowledge is used in neither the SIA guidelines nor the EIA guidelines for hydrocarbons and minerals in Greenland. Furthermore, 
for minerals there is a difference between the terms used in the SIA and the EIA guidelines, the former using traditional and local knowledge, and the latter using only local knowledge. The guidelines are in general characterized by the use of language like 'Greenlandic', 'citizen', 'local population', 'stakeholder', 'general public' and 'local inhabitant'. This is in contrast to the neighboring country of Canada, which also encompasses Inuit homelands, and where language like 'Inuit' and 'indigenous consultation' are commonly used. Inuit in both countries share a high level of self-governance and have Inuit majorities in their homelands, but the difference may be due to the Greenlandic choice of creating a public government versus the Canadian choice of creating indigenous governments.

\subsection{Key arenas for utilization of indigenous knowledge}

When looking at the typical phases of EIA and SIA processes in Greenland and the arenas where stakeholder involvement takes place, it becomes apparent that there are several entry points where indigenous knowledge can be utilized (fig. 1). A closer description of the different phases and why they constitute potential arenas for the utilization of indigenous knowledge follows below.

\section{Scoping phase: Public pre-consultation (draft ToR)}

Since 2012, a public pre-consultation has been required during the scoping phase of a project to ensure early involvement of stakeholders in Greenland. Applicants have to prepare a draft Terms of Reference (draft ToR) based on initial scoping, setting out a preliminary table of contents for the EIA and SIA reports. The draft ToR is submitted to the authorities and published on the government of Greenland website for a

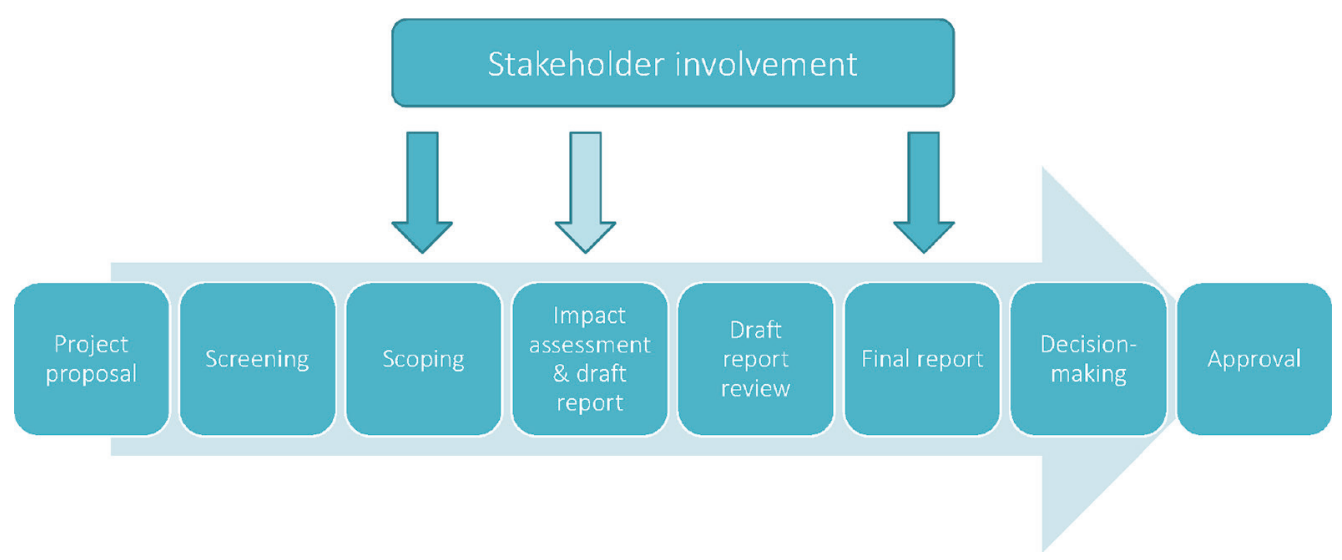

Figure 1. Typical phases of EIA and SIA processes relating to mineral resource activities in Greenland, and the arenas of stakeholder involvement that provide entry points for the utilization of indigenous knowledge. Dark arrows indicate stakeholder involvement through public consultations, and light arrows indicate stakeholder involvement in data collection and impact assessment. 
35 day public pre-consultation. The public pre-consultation provides the first entry point where indigenous knowledge can be utilized. Based on submitted comments from stakeholders, the applicant will revise the draft ToR for final approval by the government of Greenland. A white paper for the ToR containing the received comments and the responses from the applicant and authorities will be made publicly available.

\section{Impact assessment phase: Drafting the EIA and SIA reports}

Subsequent to the approval of the ToR by the authorities, the applicant can commence the process of drafting the EIA report and the SIA report. This includes a baseline study and data collection to make an environmental and a social baseline respectively. These baselines are used as the foundation on which predictions of the impact from the planned mineral resource activities are made, the significance of a negative impact on the environment or social conditions is assessed, and mitigation measures are proposed. During the impact assessment phase, consultants can draw upon knowledge from several sources. This provides the second entry point for utilizing indigenous knowledge. The draft EIA/SIA report is then submitted to the government of Greenland for the next phase.

\section{EIA/SIA report review phase: Public consultation}

When the draft EIA/SIA report fulfils the minimum requirements, it is submitted to the government of Greenland and published on the government of Greenland website for an eight week public consultation. During the eight weeks, public consultation meetings must be held in towns and settlements significantly affected, whether directly or indirectly, by the mineral resource activities. The public consultation period allows the public to submit their comments in oral form, e.g. at the public meetings, or in written submissions. This provides the third entry point where indigenous knowledge can be utilized.

When the public consultation period is over, the applicant will revise the Draft EIA/SIA reports based on the written comments submitted during the public consultation period, and the oral comments raised at the public consultation meetings. The revised EIA/SIA report is submitted for final approval by the government of Greenland. The final EIA/SIA reports provide a basis for the decision-making process with all information necessary to determine the conditions of permission and approval of the proposed mineral resource activities. A white paper for the EIA/SIA report containing the received written and oral comments, and the responses from the applicant and authorities, will be made publicly available.

Considering the stakeholder involvement that takes place during these three phases, we have identified them as arenas for the utilization of indigenous knowledge in EIA and SIA processes in relation to mineral resource activities in Greenland (fig. 2).

Besides the three arenas mentioned in Figure 2, there is at least one other arena, which may be considered relevant as an entry point for utilizing indigenous knowledge. This 


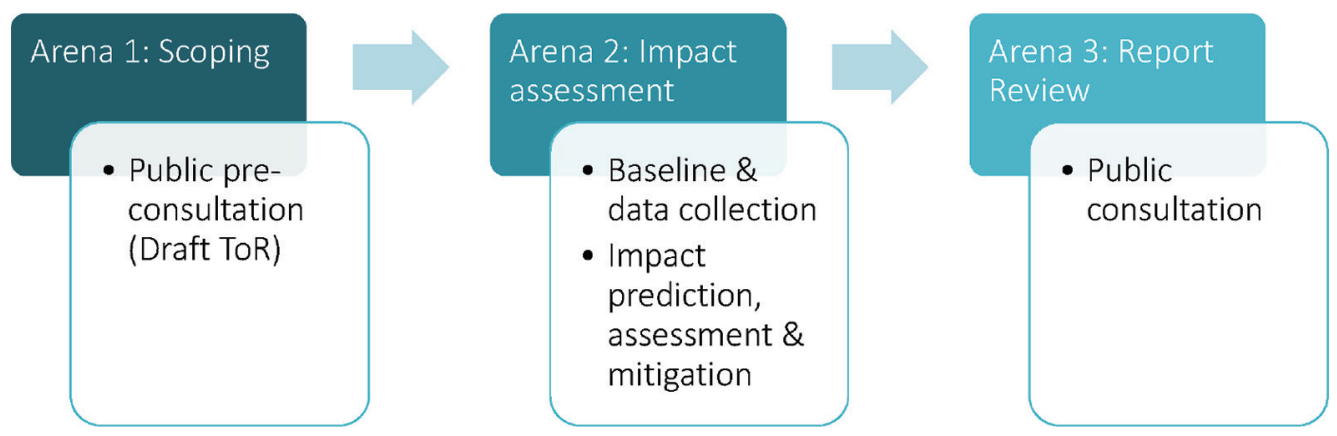

Figure 2. Overview of arenas for utilization of indigenous knowledge in EIA and SIA processes, according to regulations in relation to mineral resource activities in Greenland.

is the monitoring phase after the approval of a mineral resources activity as defined in the Environmental Management Plan, which covers the monitoring of impacts during construction, operation, closure and post-closure stages. The EIA guidelines state that:

The Environmental Management Plan shall include a comprehensive plan/programme for control and ongoing monitoring of, for instance, emissions, discharges, disturbance of and damage to wildlife.

However, there is no requirement for the involvement of stakeholders during the monitoring phase. It is therefore up to the companies to decide whether to include indigenous knowledge in the programs for this phase.

\section{Analytical approach}

The analysis presented in this paper focuses on the utilization of indigenous knowledge in the third arena as illustrated in Figure 2: SIA/EIA report review. In order to analyze the extent to which indigenous knowledge was utilized in practice, three applications for permits to establish mines in Greenland were analyzed. The three cases are the only ones that have been subject to full report review under the current EIA and SIA regimes in Greenland and therefore the only ones for which white papers for both EIA and SIA consultations had been published at the time of the analysis presented here. White papers for the three case-related EIA reports and one SIA report were analyzed.

The analysis was conducted using the constructivist strand of informed grounded theory. This is an inductive research methodology, which develops theories or hypotheses from data through systematic and iterative strategies for data collection and analysis. ${ }^{49}$ Informed grounded theory builds upon this by adding literature review strategies that take advantage of pre-existing theories and research findings in an open-minded way. ${ }^{50}$

The analysis was carried out in two steps: first, an initial screening of the white paper documents in each case was conducted to identify overall categories related 
to indigenous knowledge. Second, an in-depth analysis of the same papers was conducted, with attention to the characteristics of the comments made, including the proportion of indigenous knowledge related comments and the influence of indigenous knowledge comments on the content of the reports after revision. The two steps are further described in the following.

\subsection{Creating the frame: Screening of EIA and SIA white papers}

The first step in the document analysis presented in this paper involved a screening of white papers related to the third key arena for utilizing indigenous knowledge: the review of EIA and SIA reports. In each of the three cases subject to investigation, white papers for EIAs and SIAs were screened with the purpose of identifying where and how indigenous knowledge was included. The findings from the screening were used to frame an in-depth subsequent analysis of the same documents, as described below (section 4.2).

Based on the knowledge concepts of indigenous knowledge, traditional knowledge, traditional ecological knowledge, Inuit Qaujimajatuqangit and other related knowledge concepts (described in section 2), the descriptions of these elements of knowledge systems provided an informed foundation of what to notice in the comments. The comments were reviewed in order to identify elements that indicated knowledge, practices, values, traditions and priorities that reflect Greenlandic Inuit culture, whether as comments, criticisms or questions. Elements were coded and condensed into categories that were compared iteratively and adjusted if necessary. The initial screening led to the identification of overall categories for the topics raised in the cases, such as 'social' or 'political'. The screening further led to the identification of a number of sub-categories. Patterns in the way indigenous knowledge was revealed, by whom, and what characterized the comments were identified and noted. The categories presented in Table 1 show how the comments were ordered according to overall issues, fields and areas.

Table 1. Overview of categories of comments in white papers of three EIA and one SIA report reviews.

\begin{tabular}{lllllll}
\hline $\begin{array}{l}\text { Category of } \\
\text { comments }\end{array}$ & Introductory & Environmental & Biological & Social & Political & Information \\
\hline Sub-category & - & Technical & - & Economical & Strategic & - \\
& & Climate & & Health & Process & \\
& & Geological & & Cultural & Rights & \\
\hline
\end{tabular}

\subsection{Analysis of comments with regard to indigenous knowledge characteristics}

After the analytical framework was established, we went through the documents again, making a detailed analysis in which the categories and comments were further nuanced. We also identified the percentage of comments related to indigenous knowledge versus the total number of comments made for each case and noted 
which led to changes, such as additions to sections, reformulations or other things in the EIA and SIA reports.

Using the grounded theory approach, the documents were analyzed systematically but also in an iterative manner to recognize what could be identified as comments based on indigenous knowledge and the characteristics of these comments. Based on this analysis, four indicators of indigenous knowledge in responses in the white papers were identified. The comments all covered topics according to the list provided in section 2.1 and could be sorted according to the categories presented in table 1. Comments that contained indigenous knowledge were on topics related to traditional activities and lifestyles that could potentially relate to indigenous knowledge systems and/or involved concerns and priorities that reflected traditional and cultural values and/or involved Indigenous peoples' rights, including customary traditional rights.

\section{Data and data collection}

The white paper document summarizes consultation statements, comments and questions that were given in written or oral form during the consultation phases of the EIA and SIA processes. In addition to comments and questions raised by members of the public, the white paper includes replies from the company, comments of the relevant authorities and scientific advisors, and descriptions of how and where the conclusions made from the comments would lead to changes in the EIA/SIA report. The white papers and impact assessment reports relating to mining projects in Greenland are part of the decision-making basis for the government of Greenland, and are publicly available on the government's main website under the tab of public consultation to ensure transparency.

We screened the accessible documents from 2012 to 2015 related to three impact assessment processes, which were carried out under the regulatory regime described above. To confirm that we had the right and most recent documents, we contacted a government official who confirmed by mail and provided links to the relevant documents. The document analysis comprised three cases with associated white papers, a total of more than 500 pages were analyzed.

As mentioned in section 2.3, we reviewed these documents to identify input reflecting knowledge, experience and traditions relating to the local environment, both social and biophysical. We considered input into all sections of these documents, including the terms of reference (formal protocol), the data and data collection methods, analysis/interpretation of results, and the conclusions made. Since we did not investigate the background of the respondents and the source of their knowledge, it proved difficult to distinguish between local and indigenous knowledge. We therefore risked including too many comments during the screening. To mitigate this risk, we filtered the comments to include only those made by Greenlandic civil society and Greenlandic organizations. Other comments from Greenlandic sources 
were included when they were not purely governmental or technical in nature. It could be argued that we then could risk excluding relevant comments, however it proved possible in practice to differentiate between Greenlandic and non-Greenlandic respondents, as well as distinguish between nontechnical versus technical and procedural comments.

\section{Three mining projects}

To get an indication of how indigenous knowledge is present in white papers, we have analyzed three cases of mining projects in Greenland, based on the criteria that the projects have received licenses for exploitation, have undergone public consultation processes with public consultation meetings, and have published white papers from the EIA and SIA report review processes (table 2).

Table 2. Overview of three mining projects in Greenland.

\begin{tabular}{|c|c|c|c|c|c|}
\hline Year & Mineral(s) & Company & Location & $\begin{array}{l}\text { Link to white papers } \\
\text { (Accessed June } 6,2018 \text { ) }\end{array}$ & No. of pages \\
\hline 2015 & $\begin{array}{l}\text { Zink and } \\
\text { lead }\end{array}$ & $\begin{array}{l}\text { Ironbark } \\
\text { Zinc } \\
\text { Limited }\end{array}$ & $\begin{array}{l}\text { Citronen } \\
\text { Fjord } \\
\text { NE GL }\end{array}$ & $\begin{array}{l}\text { http://naalakkersuisut.gl/ /media/ } \\
\text { Nanoq/Files/Hearings/2015/Ironbark_ } \\
\text { SIA_EIA_NSI/Hvidboeger\%20og\%20 } \\
\text { godkendte\%20redegoerelser/White } \% 20 \\
\text { Paper_ENG_VSB.pdf } \\
\text { http://naalakkersuisut.gl/ /media/ } \\
\text { Nanoq/Files/Hearings/2015/Ironbark_ } \\
\text { SIA_EIA_NSI/Hvidboeger\%20og\%20 } \\
\text { godkendte\%20redegoerelser/Ironbark } \% 20 \\
\text { EIA\%20White\%20paper\%20ENG.pdf }\end{array}$ & $\begin{array}{l}\text { SIA } 83 \text { pages } \\
+ \text { EIA } 72 \\
\text { pages } \\
\text { ( } 115 \text { pages in } \\
\text { total) }\end{array}$ \\
\hline 2013 & Rubies & $\begin{array}{l}\text { Greenland } \\
\text { Ruby A/S }\end{array}$ & $\begin{array}{l}\text { Fiskenæsset } \\
\text { SW GL }\end{array}$ & $\begin{array}{l}\text { http://naalakkersuisut.gl/ /media/Nanoq/ } \\
\text { Files/Hearings/2013/TNG\%20QEQ/ } \\
\text { Documents/Hvidbog\%20-\%20Dan.pdf }\end{array}$ & 215 pages \\
\hline 2012 & Iron & $\begin{array}{l}\text { London } \\
\text { Mining }\end{array}$ & $\begin{array}{l}\text { ISUA } \\
\text { WG GL }\end{array}$ & $\begin{array}{l}\text { http://naalakkersuisut.gl/ /media/ } \\
\text { Nanoq/Files/Attached } \% 20 \text { Files/Raastof/ } \\
\text { Hoeringer/ISUA } \% 202012 / \text { Hvidbog } \% 20 \\
\text { London } \% 20 \text { Mining.pdf }\end{array}$ & 248 pages \\
\hline
\end{tabular}

A map showing the location of the three mining projects in Greenland can be seen in Figure 3.

\subsection{Citronen Fjord - Zinc/Lead}

The Citronen project is located in northeast Greenland. It is considered one of the world's largest undeveloped zinc-lead resources. ${ }^{51}$ Ironbark Zinc Ltd. has been exploring in the area since 2007. The pre-consultation (draft ToR) requirement is not applicable to Ironbark as their exploration license was granted before the adoption of the Mineral Resources Act in 2009. 


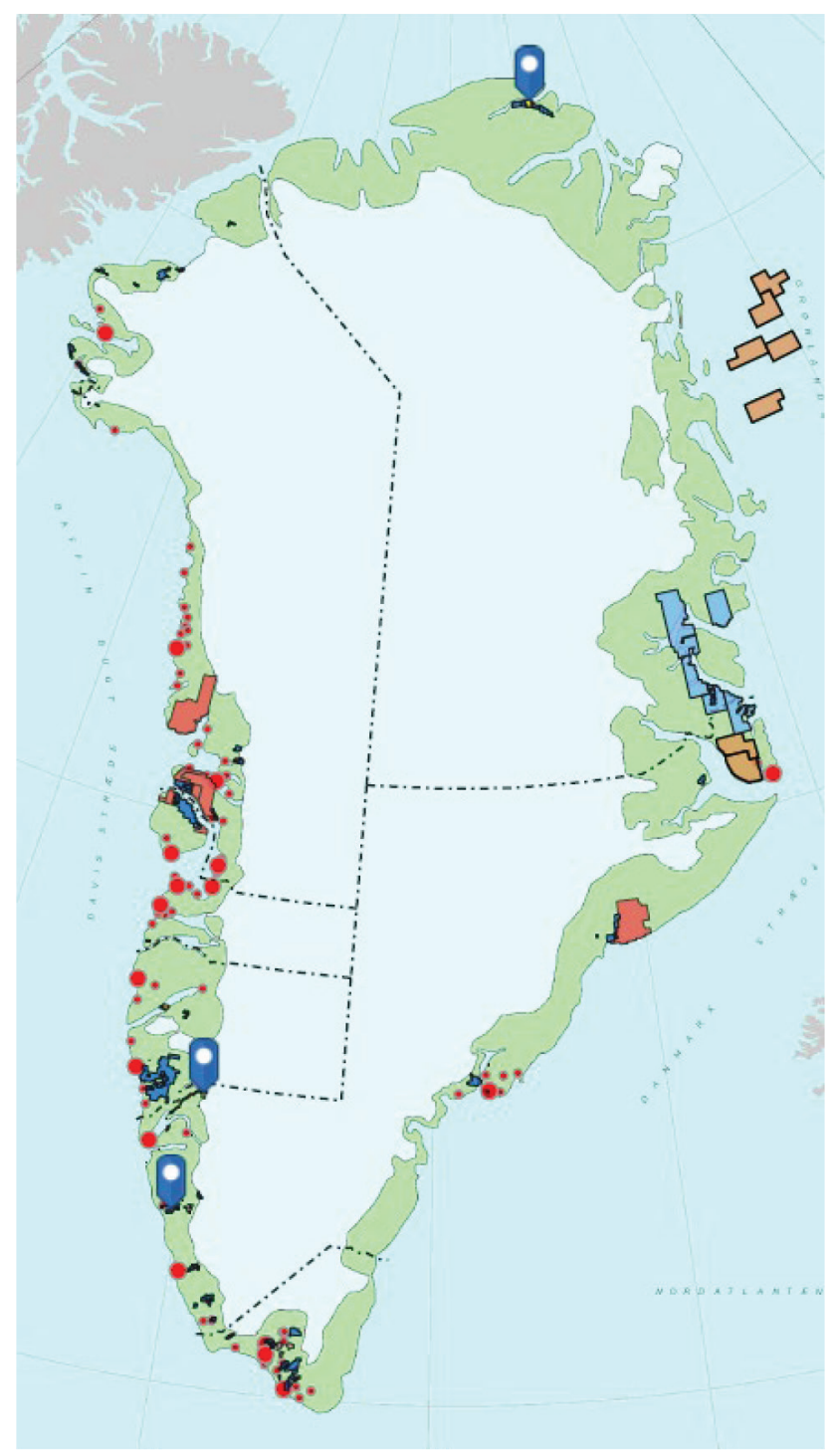

Figure 3. Greenland license map with locations of the three projects (blue markers with white dot). Adapted from the Greenland license map by Greenland Minerals Authority.

\subsection{ISUA - Iron}

The Isukasia Iron Ore project in Greenland, is approximately $150 \mathrm{~km}$ northeast of the capital Nuuk. The ISUA project was initially owned by London Mining and includes the development of an open pit mine, an ore processing plant, as well as shipping and other necessary facilities and infrastructures. ISUA contains according to the government $^{52}$ a remarkable iron formation within the so-called ISUA Greenstone Belt. Two thirds of the ore body is expected to be concealed under the inland ice cap. Exploration 
has been carried out since 2004, and London Mining Greenland A/S was granted an exploitation permit in $2013^{53}$ with financial backing provided by General Nice Development Ltd. The project is presently on hold. If the project is to move forward, then the licensee must submit an exploitation and closure plan to the government of Greenland, and will have to negotiate an IBA with the local and national authorities.

The pre-consultation (draft ToR) requirement was not applicable to London Mining as their exploration license was granted before the adoption of the Mineral Resources Act in 2009.

\subsection{Aappaluttoq - Rubies}

Aappaluttoq is located in the southern part of west Greenland. The area hosts according to the government $t^{54}$ a ruby-pink sapphire deposit. ${ }^{55}$ The area has been under exploration since 2004 by True North Gems Greenland, which was granted a license but went bankrupt in 2016. The license was awarded to LNS Greenland $\mathrm{A} / \mathrm{S}$ in 2016 and its sister company Greenland Ruby A/S took over the license and responsibility for sales and marketing, while LNS Greenland is responsible for the operation of the mine.

\section{Findings}

Our analysis of white papers showing oral and written comments received during the consultation processes for the EIA and SIA report reviews showed that comments related to indigenous knowledge tended to be on topics of climate conditions, biological issues, traditional activities, historical and cultural sites, use of land and water, and Indigenous peoples' rights.

The detailed analysis of categories and sub-categories of comments as described in section 4.2 can be seen in Appendix A with detailed descriptions of topics and issues.

The identification of comments related to indigenous knowledge made it possible to analyze the proportion of these separate from the total number of received comments, including which of them led to changes in the EIA and SIA reports. Below we summarize our analysis for each case of mining projects in Greenland.

\section{Case of Citronen Fjord}

In the white paper for the EIA report for the Citronen Fiord project, 115 comments were submitted during the public consultation including 19 comments related to indigenous knowledge. Of the total comments, 11 led to updates of the EIA report; none of those comments were related to indigenous knowledge (Table 3).

In the white paper for the SIA report for the Citronen Fjord project, 142 comments were submitted during the public consultation including 12 comments related to indigenous knowledge. Of the total comments, 18 led to updates of the SIA report, and one of the comments was related to indigenous knowledge (table 3). The remark 
related to indigenous knowledge that led to change concerned the inclusion of international agreements relating to Indigenous peoples' rights, which led to the addition of information to the report.

Table 3. Overview of oral and written comments in white papers shown in numbers and percentage of total comments, including those leading to updates in white papers related to the Citronen Fjord project.

\begin{tabular}{lcc}
\hline Citronen Fjord white papers & Total comments & $\begin{array}{c}\text { Comments related to } \\
\text { Indigenous knowledge }\end{array}$ \\
\hline EIA report & 115 & $19(16.5 \%)$ \\
- Of which led to changes to EIA report & $11(9.6 \%)$ & $0(0 \%)$ \\
SIA report & 142 & $12(8.5 \%)$ \\
• Of which led to changes to SIA report & $18(15.7 \%)$ & $1(0.7 \%)$ \\
IA reports in total & 257 & $31(12.1 \%)$ \\
• Of which led to changes in IA reports & $29(11.3 \%)$ & $1(0.4 \%)$ \\
\hline
\end{tabular}

\section{Case of ISUA}

In the combined white paper for the EIA and SIA report for the ISUA project, 321 comments were submitted during the public consultation including 17 comments related to indigenous knowledge. Of the total comments, 46 led to updates of the EIA and SIA reports; 6 of those comments were related to indigenous knowledge (table 4). The comments related to indigenous knowledge that led to changes concerned descriptions of cultural heritage sites and legislation on their protection, indicators of the impact on traditional living conditions, recommendations to coordinate with KNAPK (the Association of Fishers and Hunters in Greenland), and a correction of sled dog areas. The changes reflected the addition and correction of information in the report, and of the procedural involvement of stakeholders in this regard.

Table 4. Overview of oral and written comments in numbers and percentage of total comments, including those leading to updates in white papers related to the ISUA project. The comments to the EIA and SIA have been combined into one white paper.

\begin{tabular}{lcc}
\hline ISUA white paper & Total comments & $\begin{array}{c}\text { Comments related to } \\
\text { Indigenous knowledge }\end{array}$ \\
\hline EIA \& SIA report & 321 & $17(5.3 \%)$ \\
- Updates to EIA \& SIA report & $46(14.3 \%)$ & $5(1.6 \%)$ \\
\hline
\end{tabular}

\section{Case of Aappaluttoq}

In the white paper for the EIA report for the Aappaluttoq project, 76 comments were submitted during the public consultation including three comments related to indigenous knowledge. Of the total comments, 19 led to updates of the EIA report two of which were related to indigenous knowledge (table 5). The comments related to indigenous knowledge concerned information on eagles. 
Table 5. Overview of oral and written comments in numbers and percentage of total comments, including those leading to updates in white papers related to the Aappaluttoq project.

\begin{tabular}{lcc}
\hline Aappaluttoq white papers & Total comments & $\begin{array}{c}\text { Comments related to } \\
\text { indigenous knowledge }\end{array}$ \\
\hline EIA report & 76 & $3(3.9 \%)$ \\
- Updates to EIA report & $19(25 \%)$ & $2(2.6 \%)$ \\
SIA report & 103 & $12(11.7 \%)$ \\
- Updates to SIA report & $5(4.9 \%)$ & $1(1.0 \%)$ \\
Public consultation meetings & 47 & $1(2.1 \%)$ \\
- Updates to SIA/EIA reports & $0(0 \%)$ & $0(0 \%)$ \\
\hline
\end{tabular}

In the white paper for the SIA report for the Aappaluttoq project, 103 comments were submitted during the public consultation including 12 comments related to indigenous knowledge. Of the total comments, five led to updates of the SIA report one of which was related to indigenous knowledge (table 5). The remark related to indigenous knowledge concerned the designation of Indigenous peoples in Greenland.

A separate section in the white papers for the Aappaluttoq project contains comments from public consultation meetings in the communities of Qeqertarsuatsiaat, Paamiut, and Nuuk, and they are not differentiated between SIA and EIA topics. There were 47 comments, one of which was related to indigenous knowledge. None of the total comments led to changes in the EIA and SIA reports.

An overview of all three cases can be seen in Figure 4 below, showing the total number of comments and the proportions of indigenous comments and other

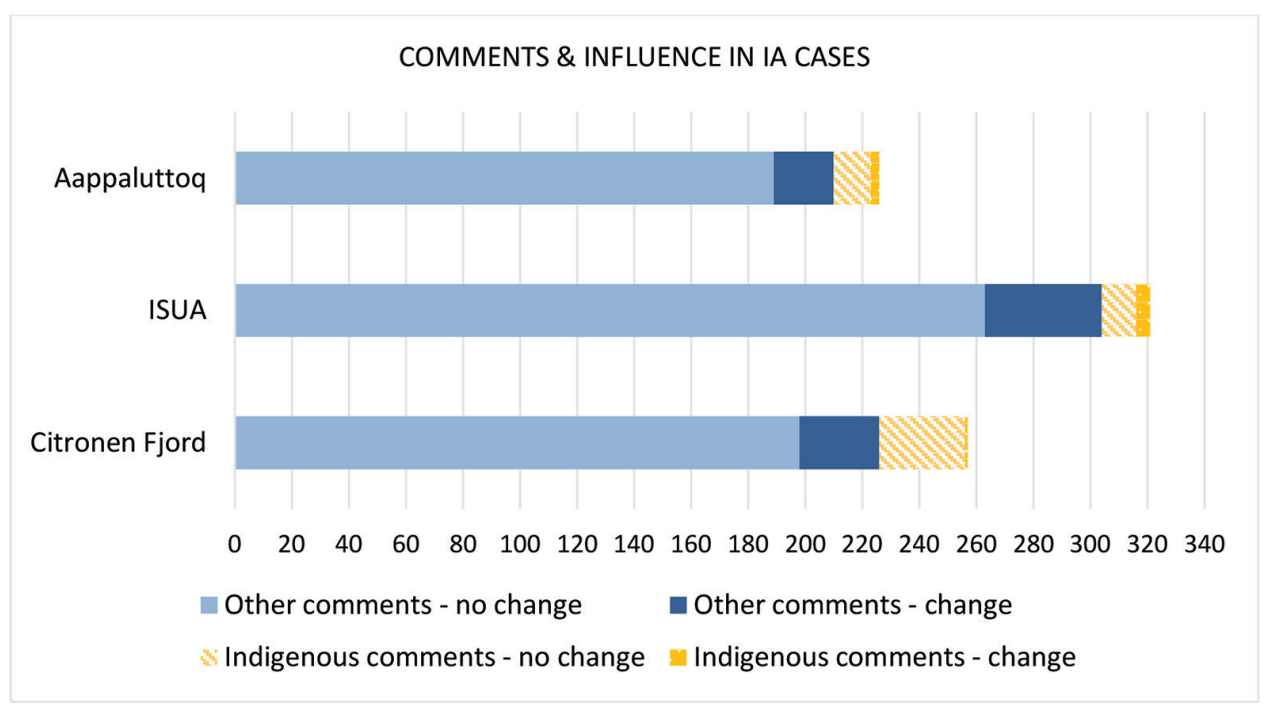

Figure 4. Diagram of all three cases showing the proportion of indigenous comments and other comments: both the ones that influenced the IA reports by leading to change, and the ones that did not influence the IA reports. 
comments, including the ones that influenced the IA reports by leading to changes in the reports and the ones that did not lead to any change.

\section{Identification of stakeholders}

From the analysis of the white papers, we found that the groups of stakeholders submitting comments could in general be categorized as:

a) Individual citizens (both Greenlandic and non-Greenlandic, some of whom commented in their personal capacity as professionals)

b) Greenlandic governmental agencies (such as ministerial departments and municipalities)

c) Greenlandic governmental institutions (such as the University of Greenland and other scientific/educational institutions, schools and the police)

d) Scientific institutions outside Greenland (such as Danish scientific institutions conducting research in Greenland)

e) Interest organizations within Greenland (including civil society organizations such as the Inuit Circumpolar Council and the Avataq, and industrial organizations such as the Greenland Business Association)

f) Interest organizations outside Greenland (including non-governmental organizations such as Greenpeace and WWF Denmark)

We found that the groups of stakeholders submitting comments related to indigenous knowledge were typically Greenlandic citizens, representatives of civil society organizations, as well as government officials in governmental agencies. The analysis also showed that indigenous knowledge comments tended to be of a more general nature, although there are a few examples with very concrete knowledge of certain areas/issues.

\section{Conclusions}

Through the study presented in this paper, we wanted to explore if and how indigenous knowledge is present in the final stages of impact assessment processes related to extractive industries in Greenland. We also aimed at developing a framework for recognizing and documenting indigenous knowledge in impact assessment processes in Greenland. The study involved analysis of a key arena for stakeholder engagement, and thus a key arena for potential utilization of indigenous knowledge. This arena involved the public participation procedures in relation to the review of draft impact assessment reports.

Through analysis of documents relating to three mining projects in Greenland, we found that issues involving elements of indigenous knowledge were raised throughout the three consultation processes investigated, but that other comments were more numerically dominant. The level of influence of the comments involving indigenous knowledge on the impact assessment reports was low in all three cases. Comments 
related to indigenous knowledge were recorded in the white papers, and some of these comments led to additional information or correction of information being incorporated in reports. These comments did not lead to any significant influence on the assessments, however, nor did they lead to adjustments in the projects' scope. For example, in the case of ISUA, the SIA report assessed the impact on traditional reindeer hunting as low. This was criticized by an Indigenous peoples' organization due to concerns of hunters about the significant long-term impact on traditional living conditions. Although the remark led to an update of the SIA report to include indicators of the impact on traditional living conditions in a monitoring plan, it did not lead to direct changes in the assessment of impact significance, project design or mitigation measures.

With regard to the second aim of the paper, the development of a methodology for investigating the presence of indigenous knowledge in impact assessment white papers, we developed an analytical framework involving four themes, which could identify elements of indigenous knowledge held by and informing the comment of a respondent. Themes that can be investigated are whether the comments indicate:

1) Knowledge about topics and issues relevant to indigenous knowledge, such as the categories provided in section 2.1 .

2) Traditional activities/lifestyles related to indigenous knowledge systems.

3) Concerns and priorities that reflect traditional/cultural values embedded in indigenous knowledge and cosmology.

4) Indigenous peoples' rights, including customary traditional rights.

Indigenous knowledge may in the future play a more central role as a resource brought into impact assessments than is the case today. International agreements such as UNDRIP and ILO 169 promote the inclusion of indigenous knowledge, and steps are being taken by various nations that have ratified these agreements to implement this conduct in domestic legislation. The recent Agreement on Enhanced International Arctic Scientific Cooperation under the auspices of the Arctic Council has reiterated the importance of encouraging the utilization of traditional and local knowledge in the planning and conduct of scientific activities. ${ }^{56}$

There seems to be a general expectation in the Greenland impact assessment guidelines however, that indigenous knowledge will inevitably be brought to the table and included in the process if participation processes/arenas allowing for it are provided. There is, however, a lack of knowledge supporting these expectations, and there is similarly a lack of experience on how to utilize indigenous knowledge in an appropriate manner once it has been brought into the assessment process.

In this paper, we have provided an initial approach for identifying and investigating indigenous knowledge in impact assessment processes. In order to go beyond the conclusions regarding the presence of comments involving indigenous knowledge in impact assessment processes, further research would be required. As we did not explore the other two key impact assessment arenas described in section 3.2, we 
cannot say whether indigenous knowledge has been utilized in the assessment process in earlier phases, or if this has influenced the number and content of comments in arena three. Furthermore, the processes subsequent to the impact assessment reports, such as conditions and requirements in government licenses, contingency plans, environmental management plans, and impact benefit agreement negotiations could be the basis for studies of the degree of inclusion of indigenous knowledge. We would therefore like to encourage further research in this field to allow for more in-depth reflection and better understanding of the utilization of indigenous knowledge in impact assessments in general. In addition, studies in relation to the evaluation of the benefits added to the process from utilizing indigenous knowledge and effective tools in this regard would be relevant to inform future guidelines for impact assessment procedures in Greenland.

\section{Acknowledgements}

We would like to express our gratitude to the Inuit Circumpolar Council, an Indigenous peoples' organization working for the rights and interests of the Inuit, for their perspectives on indigenous knowledge and its role in impact assessments. A special thank you to Mathias Barfod, governmental official at the Ministry of Industry and Energy in Greenland, who kindly provided us with an overview of documents and information related to the mining projects in Greenland.

\section{Notes}

1. Government of Greenland, “Greenland's Oil and Mineral Strategy 2014-2018, 8 February 2014." Available at: http://naalakkersuisut.gl/ /media/Nanoq/Files/Publications/Raastof/ ENG/Greenland\%20oil\%20and\%20mineral\%20strategy\%202014-2018_ENG.pdf

2. Anne Merrild Hansen et al., "Managing the Social Impacts of the Rapidly Expanding Extractive Industries in Greenland," The Extractive Industries and Society 3 (2016): 25-33.

3. Rasmus Ole Rasmussen and Arild Gjertsen, "Sacrifice Zones for a Sustainable State? Greenlandic Mining Politics in an Era of Transition," in The Will to Drill - Mining in Arctic Communities, eds. Bright Dale, Ingrid Bay-Larsen and Berit Skorstad (2018), 127-149.

4. Anne Merrild Hansen and Rachael Lorna Johnstone, "In the Shadow of the Mountain: Assessing Early Impacts on Community Development from Two Mining Prospects in South Greenland," The Extractive Industries and Society 6:2 (2019): 480-488. https://doi. org/10.1016/j.exis.2019.01.012

5. See amongst others: Emma Wilson and Florian Stammler, "Beyond Extractivism and Alternative Cosmologies: Arctic Communities and Extractive Industries in Uncertain Times," The Extractive Industries and Society 3:1 (2016): 1-8.

Leah S. Horowitz et al., "Indigenous Peoples' Relationships to Large-Scale Mining in Post-Colonial Contexts: Toward Multidisciplinary Comparative Perspectives," The Extractive Industries and Society (2018).

6. Vania Pereira et al., "The Peopling of Greenland: Further Insights from the Analysis of Genetic Diversity Using Autosomal and X-chromosomal Markers," European fournal of Human Genetics 23 (2015): 245-251. 


\section{Parnuna Petrina Egede Dahl \& Anne Merrild Hansen}

7. United Nations (UN) Human Rights Council (HRC), "National report submitted in accordance with paragraph 15 (a) of the annex to Human Rights Council resolution 5/1 Denmark. A/HRC/WG.6/11/DNK/1," (2011). Available at: https:/www.upr-info.org/sites/ default/files/document/denmark/session_11_-_may_2011/ahrcwg.611dnk1 e-2.pdf (accessed June 6, 2018).

United Nations (UN), "Declaration of the Rights of Indigenous Peoples (DRIP)." Available at: https://www.un.org/development/desa/indigenouspeoples/declaration-on-the-rights-of-indigenous-peoples.html (accessed June 6, 2018).

8. Government of Greenland, "Act on Greenland Self-Government”. Available at: https://naalakkersuisut.gl/ /media/Nanoq/Files/Attached\%20Files/Engelske-tekster/Act $\% 20$ on $\% 20$ Greenland.pdf (accessed July 1, 2019).

9. Anne Merrild Hansen, Pelle Tejsner and Parnuna Egede, "Traditional Knowledge and Industrial Development: On the Potential Use of Indigenous and Local Knowledge as a Resource to Assess Competencies in Greenland," in Perspectives on Skills: An Anthology on Informally Acquired Skills in Greenland, ed. R. Knudsen (University of Copenhagen, 2016), 152-163.

10. Hjalmar Dahl, President for the Inuit Circumpolar Council - Greenland. Personal communication, March 1, 2015.

11. Norman K. Denzin et al., Handbook of Critical and Indigenous Methodologies (Los Angeles: Sage, 2008).

12. Arctic Council, "Kiruna Declaration" (2013). Available at: https://oaarchive.arctic-council. org/bitstream/handle/11374/93/MM08_Final_Kiruna_declaration_w_signature.pdf?sequence $=1 \&$ isAllowed=y (accessed 24 October 2018).

Arctic Council, "Iqaluit Declaration" (2015). Available at: https://oaarchive.arctic-council.org/bitstream/handle/11374/662/EDOCS-2547-v1-ACMMCA09_Iqaluit_2015_Iqaluit_Declaration_formatted_brochure_low-res.PDF?sequence $=6 \&$ \&isAllowed $=\mathrm{y} \quad$ (accessed November 14, 2018).

13. International Association of Impact Assessment (IAIA), "Principles of Environmental Impact Assessment Best Practice," IAIA International Headquarters \& Institute of Environmental Assessment (Fargo, North Dakota 1999).

14. Peter Croal, Chantal Tetreault, and members of the IAIA IP Section, "Respecting Indigenous Peoples and Traditional Knowledge," International Association for Impact Assessment, Special Publication Series No. 9 (Fargo, North Dakota 2012).

15. Mark G. Stevenson, "Indigenous Knowledge in Environmental Assessment," Arctic 49:3 (1996): 278-291.

Inuit Circumpolar Council-Alaska, "Alaskan Inuit Food Security Conceptual Framework: How to Assess the Arctic from an Inuit Perspective," Technical Report (Anchorage, AK 2015).

16. See amongst others: Rasmus Kløcker Larsen, "Impact Assessment and Indigenous SelfDetermination: A Scalar Framework of Participation Options," Impact Assessment and Project Appraisal 36:3 (2018): 208-219.

Timo Koivurova and Leena Heinämäki, "The Participation of Indigenous Peoples in International Norm-Making in the Arctic," Polar Record 42:2 (2006): 101-109. DOI:10.1017/ S0032247406005080

Aniekan Udofia, Bram Noble and Greg Poelzer, "Meaningful and Efficient? Enduring Challenges to Aboriginal Participation in Environmental Assessment," Environmental Impact Assessment Review 65 (2017): 164-174.

Anna-Sofie Hurup Olsen and Anne Merrild Hansen, "Perceptions of Public Participation in Impact Assessment: A Study of Offshore Oil Exploration in Greenland," IMPACT ASSESSMENT AND PROfECT APPRAISAL 32:1 (2014): 72-80. DOI: 10.1080/14615517.2013.872842 
17. See amongst others: Esben Leifsen et al., "New Mechanisms of Participation in Extractive Governance: Between Technologies of Governance and Resistance Work," Third World Quarterly 38:5 (2017): 1043-1057. DOI: 10.1080/01436597.2017.1302329

Andrea Cornwall, "Spaces for Transformation? Reflections on Issues of Power and Difference in Participation in Development," in Participation: From Tyranny to Transformation, eds. Samuel Hickey and Giles Mohan (London: Zed Books, 2004), 75-91.

18. Larsen, "Impact Assessment and Indigenous Self-Determination: A Scalar Framework of Participation Options".

19. See amongst others: Hansen et al., "Managing the Social Impacts of the Rapidly Expanding Extractive Industries in Greenland"

Noor Johnson, "Thinking Through Affect: Inuit Knowledge on the Tundra and in Global Environmental Politics," in Non-Capitalist Political Ecologies, eds. B. J. Burke and B. W. Shear, special section of the Fournal of Political Ecology 21(2014): 127-221.

Igor Krupnik and Dyanna Jolly, eds., "The Earth Is Faster Now: Indigenous Observations of Arctic Environmental Change," in Arctic Research Consortium of the United States (Fairbanks, Alaska 2002).

20. See amongst others: Tim Ingold, The Perception of the Environment: Essays in Livelihood, Dwelling and Skill (New York: Routledge 2000).

Henry P. Huntington, "Observations on the Utility of the Semi-Directive Interview for Documenting Traditional Ecological Knowledge," Arctic 51:3 (The Arctic Institute of North America 1998): 237-242.

Frank Duerden, "Translating Climate Change Impacts at the Community Level," Arctic 57:2 (The Arctic Institute of North America 2004): 204-212.

21. See amongst others: Ingold, The Perception of the Environment: Essays in Livelihood, Dwelling and Skill.

Arlene Stairs and George W. Wenzel, "I am I and the Environment: Inuit Hunting, Community and Identity," Fournal of Indigenous Studies 3:1 (1992): 1-12.

Aniekan Udofia, Bram Noble and Greg Poelzer, "Meaningful and Efficient? Enduring Challenges to Aboriginal Participation in Environmental Assessment," Environmental Impact Assessment Review 65 (2017): 164-174.

22. See amongst others: Parnuna Egede Dahl and Pelle Tejsner, Manuscript submitted for publication to Routledge Handbook on Indigenous Peoples in the Arctic, 1-16.

Marc G. Stevenson, "Indigenous Knowledge in Environmental Assessment," Arctic 49:3 (1996): 278-291.

23. See amongst others: Paul Nadasdy, "The Politics of TEK: Power and the 'Integration' of Knowledge," Arctic Anthropology 36:1-2 (1999): 1-18.

George W. Wenzel, "Traditional Ecological Knowledge and Inuit: Reflections on TEK Research and Ethics," Arctic 52:2 (1999): 113-124.

Peter J. Usher, "Traditional Ecological Knowledge in Environmental Assessment and Management," Arctic 53:2 (2000): 183-193.

Frank Sejersen, "Hunting in Greenland and the Integration of Local Users' Knowledge in Management Strategies," in Aboriginal Environmental Knowledge in the North, eds. Louis-Jacques Dorais, Murielle Nagy, and Ludger Müller-Wille (Quebec: Gétic 1998), 37-60.

24. Usher, "Traditional Ecological Knowledge in Environmental Assessment and Management".

25. Frank Sejersen, "Hunting in Greenland and the Integration of Local Users' Knowledge in Management Strategies."

26. See amongst others: N. Thorpe, et al., Reviewed Work(s): "Thunder on the Tundra: Inuit Qaujimajatuqangit of the Bathurst Caribou," Arctic 55:4,(2002): 395-396. 


\section{Parnuna Petrina Egede Dahl \& Anne Merrild Hansen}

George W. Wenzel, "From TEK to IQ: Inuit Qaujimajatuqangit and Inuit Cultural Ecology," Arctic Anthropology 41:2 (2004): 238-250.

E. Keenan, L. M. Fanning, and C. Milley, "Mobilizing Inuit Qaujimajatuqangit in Narwhal Management Through Community Empowerment: A Case Study in Naujaat, Nunavut," Arctic 71:1 (2017): 27-39.

27. George W. Wenzel, "From TEK to IQ: Inuit Qaujimajatuqangit and Inuit Cultural Ecology."

28. Ibid., 241.

29. Ibid., 248.

30. Noor Johnson, "Thinking Through Affect: Inuit knowledge on the Tundra and in Global Environmental Politics."

31. Inuit Circumpolar Council. (2013). "Application of Traditional Knowledge in the Arctic Council," 2 p. Retrieved 1 June, 2017, from http://iccalaska.org/wp-icc/wp-content/uploads/2016/03/Application-of-Traditional-Knowledge-in-the-Arctic-Council.pdf

32. Arctic Council Permanent Participants, "Ottawa Traditional Knowledge Principles," Arctic Council Indigenous Peoples Secretariat (2015). Available at: https://www.arcticpeoples.com/ our-work-2/\#traditional-knowledge-1

33. Inuit Circumpolar Council, "Application of Indigenous Knowledge in the Arctic Council" (2016). Available at: http://iccalaska.org/wp-icc/wp-content/uploads/2016/03/Applicationof-IK-in-the-Arctic-Council.pdf (accessed June 6, 2018)

34. Permanent Participants, "Arctic Indigenous Peoples at the Second Arctic Science Ministerial” (2018). Available at: https://iccalaska.org/wp-icc/wp-content/uploads/2018/10/ICC_PPpress-release_1026.pdf (accessed November 11, 2018).

35. Inuit Circumpolar Council, "Application of Indigenous Knowledge in the Arctic Council" (2016). Available at: http://iccalaska.org/wp-icc/wp-content/uploads/2016/03/Applicationof-IK-in-the-Arctic-Council.pdf (accessed 6 June, 2018).

36. Ketil Fred Hansen and Nigel Bankes, "Human Rights and Indigenous Peoples in the Arctic," in Arctic Oil and Gas: Sustainability at Risk? eds. Aslaug Mikkelsen and Oluf Langhelle (New York: Routledge 2013), 301.

37. Nordic Council of Ministers, "Local Knowledge and Resource Management: On the Use of Indigenous and Local Knowledge to Document and Manage Natural Resources in the Arctic."

38. Ole Geertz-Hansen, Senior Researcher, Greenland Institute of Natural Resources. Personal communication, April 23, 2018.

39. Government of Greenland website, "Facts on Greenland". Available at: http://naalakkersuisut.gl/en/About-government-of-greenland/About-Greenland/Facts-on-Greenland (accessed June 6, 2018).

40. A. Nicole Stuckenberger, "Anthropologists Engaging in Climate Change Education and Outreach: Curating Thin Ice - Inuit Traditions within a Changing Environment," in Anthropology and Climate Change, eds. Susan Alexandra Crate and Mark Nuttall (Walnut Creek: Left Coast Press 2009), 383.

41. See amongst others: Environmental Agency for Mineral Resource Activities (EAMRA), "Offshore Seismic Surveys in Greenland - Guidelines to Best Environmental Practices, Environmental Impact Assessments and Environmental Mitigation Assessments" (2015). Available at: https://www.govmin.gl/images/Documents/Terms_guidelines_hydrocarbons/ Environmental_Impact_Assessment_Guidelines.pdf (accessed July 2, 2018).

Bureau of Minerals and Petroleum (BMP), "BMP Guidelines - For Preparing an Environmental Impact Assessment (EIA) Report for Activities Related to Hydrocarbon Exploration and Exploitation of Offshore Greenland" (2011). Available at: https://www.govmin.gl/images/stories/petroleum/BMP_EIA_Guidelines_Jan_2011.pdf (accessed July 2, 2018). 
42. Environmental Agency for Mineral Resource Activities (EAMRA), "Offshore Seismic Surveys in Greenland - Guidelines to Best Environmental Practices, Environmental Impact Assessments and Environmental Mitigation Assessments" (2015). Available at: https://www. govmin.gl/images/Documents/Terms_guidelines_hydrocarbons/Environmental_Impact_Assessment_Guidelines.pdf (accessed July 2, 2018) (EAMRA EIA $\mathcal{E}$ EMA Guidelines, p. 34).

43. Government of Greenland, Ministry of Industry, Labour and Trade, "Social Impact Assessment (SIA) Guidelines on the Process and Preparation of the SIA Report for Mineral Projects" (2016). Available at: https://www.govmin.gl/images/Documents/Socio_Economics/SIA_guideline.pdf (accessed May 29, 2018).

44. Ibid., 24.

45. Government of Greenland, Mineral Resources Authority, "Guidelines for Preparing an Environmental Impact Assessment (EIA) Report for Mineral Exploitation in Greenland" (2015). Available at: https://govmin.gl/images/stories/minerals/Guidelines_for_preparing_an_Environmental_Impact_Assessment_EIA_report_for_mineral_exploitation_in.pdf (accessed May 29, 2018).

46. Ibid., 10 .

47. Ibid.

48. Government of Greenland, Ministry of Industry, Labour and Trade, "Social Impact Assessment (SIA) Guidelines on the Process and Preparation of the SIA Report for Mineral Projects" (2016). Available at: https://www.govmin.gl/images/Documents/Socio_Economics/SIA_guideline.pdf (accessed May 29, 2018).

49. K. Charmaz, Constructing Grounded Theory, 2nd Edition (Los Angeles: SAGE. 2014).

50. R.Thornberg, "Informed Grounded Theory," Scandinavian fournal of Educational Research 56:3 (Routledge 2012): 243-259.

51. Government of Greenland, "Mineral Occurrences: Mineralizing Environments and Related Mineral Occurrences Throughout Greenland's Geological History” (2018). Available at: https://www.govmin.gl/en/minerals/mineral-occurrences (accessed May 31, 2018).

52. Ibid.

53. Ibid.

54. Ibid.

55. Tetra Tech EBA Inc., "Updated Pre-Feasibility Study on the Aappaluttoq Ruby Project, Greenland - National Instrument 43-101. Technical Report - Presented to True North Gems Inc.” (2011). Available at: http://www.truenorthgems.com/wp-content/uploads/2015/05/ Aappaluttoq-PFS-report-2015.pdf (accessed August 2018).

56. Arctic Council website 2018, "Agreement on Enhancing International Arctic Scientific Cooperation.” Available at: https://oaarchive.arctic-council.org/handle/11374/1916 (accessed November 22, 2018). 